\title{
O współczesnych badaniach krakowskich nad włoskim faszyzmem. \\ Rozważania wokól prac \\ Malgorzaty Kiwior-Filo i Joanny Sondel-Cedarmas
}

I. Krakowski ośrodek akademicki znany jest i ceniony już w Polsce, a nawet poza jej granicami, z badań nad autorytaryzmem i totalitaryzmem. Od wielu lat koncentrują się one zwłaszcza na Wydziale Studiów Międzynarodowych i Politycznych Uniwersytetu Jagiellońskiego, a konkretnie rzecz ujmując - prowadzone są przede wszystkim przez zespoły pracowników naukowych skupionych do niedawna wokół zmarłego w 2015 r. profesora Wiesława Kozub-Ciembroniewicza i nadal wokół profesora Marka Bankowicza. Obaj uczeni owocnie współpracowali zresztą ze sobą w dziedzinie naukowej ${ }^{1}$. Pierwszy z nich już dawno temu dał się poznać jako wytrawny znawca włoskiego faszyzmu, bodaj najlepszy w Polsce. Prócz niego zajmowało się tą problematyką jeszcze tylko kilku innych badaczy, w tym Jerzy W. Borejsza, Stanisław Sierpowski i Piotr Podemski. Należy przypomnieć, że spod pióra Kozub-Ciembroniewicza wyszły m.in. 2 wartościowe monografie książkowe na ten temat, nie licząc drobniejszych publikacji ${ }^{2}$. Nie ulega wątpliwości, że na intelektualną sylwetkę tego uczonego znaczny wpływ wywarł prof. Konstanty Grzybowski, którego Kozub-Ciembroniewicz nieodmiennie uważał za swego mistrza i mentora. Przy różnych okazjach starał się zresztą podkreślać

1 Wspólnie ogłosili oni drukiem monografię książkową Dyktatury i tyranie. Szkice o niedemokratycznej władzy (Kraków 2007), w której przekonująco ukazali istotę i przejawy autorytaryzmu i totalitaryzmu na przykładzie faszystowskich Włoch, III Rzeszy i Związku Sowieckiego.

${ }^{2}$ W 1992 r. w Wydawnictwie Uniwersytetu Jagiellońskiego ukazała się jego książka Doktryny włoskiego faszyzmu i antyfaszyzmu w latach 1922-1939, a w 2011 r. książka Doktryna i system władzy Włoch faszystowskich na tle porównawczym. M.in. pod redakcją tego uczonego wydano w tym Wydawnictwie, także w 2011 r., opracowanie zbiorowe Totalitaryzmy XX wieku. Idee - instytucje - interpretacje, będące pokłosiem międzynarodowej konferencji zorganizowanej na ten temat w Krakowie w 2007 r. 
zasługi tego wybitnego uczonego dla rozwoju badań nad historią państwa, prawa i myśli politycznej ${ }^{3}$.

Szczególne zainteresowania prof. Kozub-Ciembroniewicza włoskim faszyzmem spowodowały podjęcie przez niektórych podopiecznych tego uczonego badań właśnie nad tą problematyką. Pod jego naukowym kierunkiem kontynuowały ją i rozwijały - m.in. na poziomie rozpraw doktorskich i habilitacyjnych - dwie młode uczone: Małgorzata Kiwior-Filo i Joanna Sondel-Cedarmas. To przede wszystkim o osiągnięciach tych autorek traktuje niniejszy artykuł. Już w tym miejscu mogę jednoznacznie stwierdzić, że wniosły one - każda osobno - spory wkład w rozwój badań nie tylko nad problematyką samego faszyzmu w Italii, ale również nad pokrewnymi zagadnieniami naukowymi. W tym kontekście należy wspomnieć o funkcjonującym przy Uniwersytecie Jagiellońskim Centrum Badania Holokaustu (powstałym z inicjatywy prof. Kozub-Ciembroniewicza i kierowanym przez niego do czasu swej przedwczesnej śmierci) czy o działającym w Oświęcimiu przy Państwowej Wyższej Szkole Zawodowej im. W. Pileckiego Międzynarodowym Centrum Badania Totalitaryzmów, Zagłady i Praw Człowieka (kierowanym przez innego uczonego z Uniwersytetu Jagiellońskiego - prof. Witolda Stankowskiego) oraz o owocnej współpracy kilku krakowskich pracowników naukowych (głównie wyżej wymienionych badaczy) z wydawanymi już od ponad 40 lat we Wrocławiu, unikalnymi w skali światowej, założonymi przez prof. Karola Joncę „Studiami nad Faszyzmem i Zbrodniami Hitlerowskimi” (aktualnie ukazującymi się pod tytułem „Studia nad Autorytaryzmem i Totalitaryzmem”).

W pokrótce scharakteryzowane przeze mnie osiągnięcia krakowskich badaczy rzeczonej problematyki niewątpliwie wpisuje się swymi publikacjami wspomniana Małgorzata Kiwior-Filo, adiunkt z habilitacją z Katedry Współczesnych Doktryn Politycznych Uniwersytetu Jagiellońskiego. Jeszcze podczas studiów w Instytucie Nauk Politycznych tej szacownej uczelni zainteresowała się ona włoską myślą polityczną, przebywając w tym celu w latach 1990-1992 na stypendium na Uniwersytecie La Sapienza w Rzymie i w tamtejszym Centrum Kultury i Języka Włoskiego, gdzie posiadła także znajomość pięknej mowy Dantego czy Petrarki. Od tego czasu Kiwior-Filo niemal bez przerwy utrzymuje ożywione i korzystne kontakty naukowe z ośrodkami akademickimi we Włoszech. W wyniku pobytu na stypendiach w Italii na początku ostatniej dekady XX w. napisała ona pracę magisterską o doktrynie wolności w ujęciu wybitnego intelektualisty Benedetta Crocego, uważanego za czołowego przedstawiciela idealizmu i estetyki ekspresjonizmu we Włoszech w ubiegłym stuleciu, pozostającego pod wpływem neokantyzmu, ale również heglizmu. Tego samego filozofa, estetyka, krytyka literackiego, publicystę i liberalnego polityka w jednej

${ }^{3}$ Zob. W. Kozub-Ciembroniewicz, Konstanty Grzybowski-uczony, homo politicus, publicysta, [w:] Konstanty Grzybowski-myśliciel sceptyczny, Kraków 2000, s. 5 i n. 
osobie dotyczyła obroniona przez Małgorzatę Kiwior-Filo w 2002 r. rozprawa doktorska, oparta na szerokiej bazie źródłowej, w tym na dokumentach z Archiwum Crocego w Neapolu i Centralnego Archiwum Państwowego w Rzymie, a nawet na rozmowach autorki z jego córkami. Wszystko to należy zapisać na jej naukowy plus, choćby ze względu na pionierski w Polsce charakter tej pracy, nie mówiąc już o znaczeniu intelektualnego dorobku samego Crocego i jego wpływie na kulturę europejską od schyłku XIX w. Swymi publikacjami Kiwior-Filo zapewne przybliżyła polskiemu czytelnikowi postać tego myśliciela.

W swej rozprawie doktorskiej krakowska badaczka przedstawiła krytyczny stosunek Crocego do włoskiego faszyzmu, akcentując ewolucję jego doktryny politycznej, która ze swej liberalnej istoty kłóciła się z założeniami autorytaryzmu i nacjonalizmu przyświecającymi Benicie Mussoliniemu i jego akolitom. Szkoda, że dysertacja ta nie została opublikowana ${ }^{4}$. Dr Kiwior-Filo wyrosła bowiem na specjalistkę w rzeczonej problematyce, w zasadzie jedyną w Polsce, co nie oznacza, że jej zainteresowania naukowe nigdy nie wykraczały w ogóle poza koncepcje Crocego. Niewątpliwie koncentrowały się one jednak, przez całą niemal ostatnią dekadę XX w., właśnie na poglądach tego intelektualisty. Można nawet odnieść wrażenie, że badaczka z Uniwersytetu Jagiellońskiego nadmiernie starała się eksplorować i eksponować tę tematykę naukową. Wszystkie jej publikacje z tej dziedziny, powstałe jeszcze przed doktoratem, dotyczyły nie tyle samej filozofii Crocego z jego koncepcją absolutnego historyzmu, ile krytycznego stosunku tego myśliciela do rozmaitych przejawów faszyzmu w jego ojczyźnie, trudnych zresztą do pogodzenia - o czym wzmiankowałem $-\mathrm{z}$ jego postawą intelektualną i etyczno-estetyczną. Przypomnę, że Croce zasłynął nie tylko w Italii swym antyfaszystowskim manifestem z 1925 r. ${ }^{5}$ Nie od samego zarania faszyzmu był on jednak bezwzględnie krytyczny wobec niego, a nawet dostrzegał w tym zjawisku politycznym pewne cechy pozytywne. Już około połowy lat dwudziestych minionego stulecia zupełnie i ostatecznie zraził się do niego - przede wszystkim, choć nie wyłącznie z ideowych powodów. Nieprzypadkowo według tego filozofa rzeczywistość stanowiła przejaw wielopostaciowej aktywności ducha, co nie miało wszakże nic wspólnego z raczej prymitywnymi koncepcjami faszystów, którzy także odwoływali się do doktryny heglizmu, ale nader wybiórczo i powierzchownie ${ }^{6}$.

${ }^{4}$ We fragmentach ukazała się ona drukiem m.in. w „Studiach nad Faszyzmem i Zbrodniami Hitlerowskimi”. Zob. artykuły M. Kiwior-Filo: Benedetto Croce - krytyk faszyzmu w polskiej historiografii (1999, t. XXII); Krytyka totalitaryzmu faszystowskiego przez Benedetta Crocego w latach 1925-1943 (2002, t. XXV); Myśl Benedetta Crocego wobec genezy i rozwoju faszyzmu wloskiego w latach 1919-1925 (2001, t. XXIV).

${ }^{5}$ B. Croce, Parole pronunziate nella riunione del Consiglio Nazionale del Partito Liberale In Roma (28 giugno 1925), [w:] idem, Pagine sparse, t. II, Bari 1960, s. 493 i n.

${ }^{6} \mathrm{~W}$ polskiej literaturze najpełniej przedstawił ideowe założenia włoskiego faszyzmu W. Kozub-Ciembroniewicz m.in. w przytoczonych już dwóch monografiach książkowych oraz w kilku artykułach w „Studiach nad Faszyzmem i Zbrodniami Hitlerowskimi”. 
Po obronie rozprawy doktorskiej Kiwior-Filo już generalnie nie wracała do zagadnień odnoszących się do samego Crocego, nie odcinając - jak to nierzadko bywa - naukowych „kuponów” od swojej dysertacji, powielających zawarte w niej ustalenia w postaci drobnych artykułów czy studiów. Jednym z dwóch wyjątków od tej zasady stanowi opracowany przez nią obszerny biogram Crocego, który został zamieszczony w opracowaniu zbiorowym na temat współczesnych doktryn politycznych i prawnych ${ }^{7}$. Innym wyjątkiem jest artykuł - skądinąd ciekawy - o poglądach tego intelektualisty na faszyzację Włoch i sposoby jej przeciwdziałania poprzez rozwój instytucji demokratycznych. Kiwior-Filo wskazała zatem w tej publikacji nie tylko na negatywny stosunek Crocego do faszyzmu, ale także omówiła - co prawda tylko w zarysie - elementy pozytywnego programu tego filozofa, który nie zamierzał występować jedynie w roli krytyka ówczesnej rzeczywistości politycznej we Włoszech, lecz formułował założenia jej zmiany w kierunku liberalnym. W miarę rozwoju faszyzmu i narastania systemu totalitarnego w Italii był on bowiem coraz bardziej przekonany o konieczności dokonania takich przeobrażeń. Można przypuszczać, że właśnie badania nad filozoficznymi i politycznymi koncepcjami Crocego skierowały uwagę tej autorki na szerszą problematykę włoskiego liberalizmu, wykraczającą już poza analizę poglądów tylko tego intelektualisty. Przypomnę, że Croce był jednym z wybitniejszych reprezentantów tej politycznej doktryny w Italii, a nawet poza tym krajem, co zresztą jednoznacznie wynika z wnikliwych i przekonujących ustaleń KiwiorFilo poczynionych już po doktoracie.

Od początku obecnego stulecia badaczka z Uniwersytetu Jagiellońskiego coraz bardziej i głębiej zaczęła drążyć i penetrować problematykę włoskiego liberalizmu pierwszej połowy XX w. Niewątpliwie najważniejszym osiągnięciem naukowym Kiwior-Filo w tej dziedzinie jest jej monografia książkowa - będąca rozprawą habilitacyjną - dotycząca stosunku włoskich liberałów do rodzimego faszyzmu ${ }^{8}$. Jak już wzmiankowałem, zainteresowania autorki tymi zagadnieniami sięgają wczesnego okresu jej aktywności badawczej. Wiążą się bowiem z podjętymi przez nią rozległymi studiami nad doktryną Benedetta Crocego. Rozprawę doktorską Kiwior-Filo o tym liberalnym intelektualiście można potraktować jako zapowiedź i zaczyn jej pracy habilitacyjnej. O ile przedmiotem dysertacji z 2002 r. był w zasadzie tylko sam Croce, o tyle w rozprawie habilitacyjnej omówieni zostali również inni włoscy liberałowie pierwszej połowy XX w. Jest to zatem drugie opracowanie, znacznie bardziej tematycznie rozbudowane od pracy doktorskiej Kiwior-Filo sprzed kilkunastu lat. Choć jej rozprawa habilitacyjna zawiera także wywody

${ }^{7}$ M. Kiwior-Filo, Croce Benedetto, [w:] Wspótczesne doktryny polityczne I prawne. Twórcy - idee - interpretacje. Podręcznik akademicki, red. W. Kozub-Ciembroniewicz, B. Szlachta, A. Citkowska-Kimla, M. Kiwior-Filo, Kraków 2012, s. 54 i n.

${ }^{8}$ M. Kiwior-Filo, Myśl polityczna włoskich liberałów wobec faszyzmu, Kraków 2013, ss. 245. 
o poglądach Crocego, co zrozumiałe ze względu na jej zakres badawczy - to jednak nie dominują one w tekście tej pracy, lecz stanowią tylko jeden z wielu elementów składających się na przedstawianą narrację naukową. Można więc stwierdzić, że autorka wyraźnie poszerzyła - przedmiotowo i podmiotowo problematykę swych badawczych zainteresowań włoskim liberalizmem. Co by nie powiedzieć o wartości poszczególnych fragmentów rozprawy habilitacyjnej, w rezultacie tego zabiegu intelektualnego starała się stworzyć monografię zawierającą już nie tylko analizę doktryny jednego myśliciela liberalnego, lecz podjęła próbę napisania syntezy całego nurtu liberalnego we Włoszech w okresie faszystowskim. Co prawda owo dążenie do kompleksowego ujęcia myśli liberalnej na gruncie włoskim odnosi się przede wszystkim do kwestii stosunku jej twórców do rodzimego faszyzmu, z rozważań KiwiorFilo wyłania się zapewne niezupełnie pełny, ale mimo to niepozbawiony cech ogólności obraz tego systemu doktrynalnego w Italii w pierwszej połowie minionego stulecia. Na marginesie: nie tylko oblicze tamtego liberalizmu, lecz również założenia innych nurtów ideowych we Włoszech (np. nacjonalizmu czy socjalizmu) w znacznym stopniu wyznaczały ich odniesienia do faszyzmu, przynajmniej w latach 1919-1945, a więc w dość długim okresie historycznym.

W związku z powyższą konstatacją nasuwa się jednak istotna uwaga, a nawet swego rodzaju zarzut wobec Kiwior-Filo. Dotyczą one kwestii samej myśli liberalnej jako modelu teoretycznego. W omawianej rozprawie zabrakło przedstawienia właśnie od tej strony doktryny liberalizmu. Za niewystarczające uważam ograniczenie się przez autorkę do nader pobieżnego wskazania jedynie we wstępie do jej monografii kilku podstawowych cech liberalizmu. Nie chodzi przy tym o szeroką analizę tej problematyki, co wykraczałoby poza tematyczne ramy rozprawy o stosunku włoskich liberałów do faszyzmu, ale o udzielenie (w oparciu o zwięzłe i syntetyczne wywody o samym liberalizmie) odpowiedzi - której nie ma w tej monografii - na pytanie o miejsce włoskiego liberalizmu w tym systemie doktrynalnym oraz o - co także ważne - określenie znaczenia owego liberalizmu wśród innych nurtów ideowych w Italii w omawianym okresie historycznym. Choćby pobieżnych rozważań na ten temat również zabrakło w rozprawie habilitacyjnej Kiwior-Filo. Jak wiadomo, liberalizm nigdy nie był i nadal nie jest jednorodnym kierunkiem doktrynalnym. Można przecież wyróżnić na przestrzeni kilku ostatnich stuleci co najmniej kilka rodzajów liberalizmu, a nawet dyskutować o „gąszczu” liberalizmów, jak to przed laty ujął Jacek Bartyzel, skądinąd raczej niechętny tej ideologii ${ }^{9}$. W dodatku w każdym państwie przybiera ona nieco odmienne

9 J. Bartyzel, W gąszczu liberalizmów. Próba periodyzacji i klasyfikacji, Lublin 2004 i późn. wyd. W ostatnim ćwierćwieczu powstało w Polsce sporo publikacji o liberalizmie, a jednym z najlepszych znawców tej problematyki jest Z. Rau, autor m.in. książki Liberalizm. Zarys myśli politycznej XIX i XX wieku (Warszawa 2000). 
postacie czy odcienie, $\mathrm{z}$ różnym zresztą nasileniem, choć wykazuje również pewne wspólne cechy z liberalizmem w innych krajach. A skoro o tym mowa, to należy pamiętać, że w państwach słabo rozwiniętych gospodarczo, czyli tam, gdzie nie było silnych stosunków kapitalistycznych, upowszechnianie się koncepcji liberalnych napotykało na liczne przeszkody.

Do takich państw niewątpliwie zaliczały się w XIX w. i w pierwszej połowie następnego stulecia właśnie Włochy - w przeciwieństwie do Wielkiej Brytanii, USA, Niemiec, a nawet Francji w tamtym okresie. Można nawet zaryzykować twierdzenie, że gdyby liberalizm we Włoszech był wtedy silnie rozwinięty, nie tylko w aspekcie wynikającym z upowszechniania się stosunków kapitalistycznych, ale również ze względu na budowę stabilnego systemu parlamentarnego - znacznie trudniej byłoby faszystom odnieść spektakularny sukces polityczny, czyli ustanowić własne rządy dyktatorskie. Problem ten raczej umknął uwagi Kiwior-Filo. Nie zadawala w związku z tym ograniczenie się przez nią do wyrażenia opinii, że na ideowym obliczu włoskiego liberalizmu najbardziej wycisnęła piętno specyfika dążeń narodowo-wyzwoleńczych w Italii w XIX w. (Risorgimento). Takie ujęcie istoty tamtejszego liberalizmu jest wprawdzie uzasadnione ówczesnymi wydarzeniami historycznymi, ale wydaje się jednak dość płytkie i mało precyzyjne oraz nie do końca wyjaśniające te ważne zagadnienia badawcze. Implikuje bowiem wątpliwą tezę, że brak własnej państwowości (w przypadku Włoch brak zjednoczonego organizmu polityczno-terytorialnego) niejako automatycznie skutkuje brakiem, a co najmniej słabością doktryny liberalnej. Tymczasem jej przedstawiciele, zwłaszcza zaś teoretycy klasycznej wersji liberalizmu, opartej m.in. na koncepcjach Adama Smitha, nie przywiązują - jak wiadomo - szczególnej wagi do instytucji państwa, które uważają za swego rodzaju zło konieczne, sprzeciwiając się w związku z tym jego omnipotencji. W każdym razie nie apoteozują oni państwa, sprowadzając jego działalność do funkcji „stróża nocnego”, mającego wszakże chronić prawa i wolności swoich obywateli.

Przechodząc do pozostałych kwestii merytorycznych zawartych w rozprawie o stosunku włoskich liberałów do faszyzmu, za dobrze przemyślany i trafny uważam jej wewnętrzny układ. Opiera się on przede wszystkim na kryterium chronologicznym, które umożliwiło autorce prześledzenie ewolucji stosunku włoskich liberałów do rodzimego faszyzmu niemal od momentu narodzin tego zjawiska politycznego aż po jego upadek pod koniec II wojny światowej. Postawione przez nią tezy oraz wysnute z nich wnioski na ogół brzmią przekonująco, a zastosowaną historyczno-opisową metodę badawczą należy uznać za właściwą dla tej monografii. $Z$ obowiązku recenzenta jedynie odnotuję zatem kilka spraw dotyczących konstrukcji rozprawy. Jej dwa pierwsze rozdziały mają charakter wprowadzający do zasadniczego problemu badawczego, czyli do kwestii określenia stosunku włoskich liberałów do ruchu i ideologii Mussoliniego i jego zwolenników. Mowa w nich o wspomnia- 
nych tradycjach liberalnych doby Risorgimento oraz o źródłach i rozwoju myśli liberalnej we Włoszech, zwłaszcza w kontekście idei narodowej, która kształtowała się właśnie w tamtym okresie, podobnie zresztą jak na ziemiach polskich pod zaborami w XIX w. Krakowska badaczka umiejętnie wskazuje w swych rozważaniach na ten temat odniesienia między myślą liberalną i koncepcjami nacjonalistycznymi $\mathrm{w}$ Italii $\mathrm{w}$ tamtym stuleciu i na początku $\mathrm{XX}$ w.

Po tych wprowadzających we właściwą problematykę swej rozprawy wywodach przechodzi do prezentacji poglądów włoskich liberałów na faszyzm, najpierw w początkowym okresie jego kształtowania się, czyli przed marszem bojówek Mussoliniego na Rzym i w pierwszych trzech latach po zdobyciu przez faszystów władzy politycznej w Italii w 1922 r., a zatem w czasach przed ustanowieniem przez nich w pełni dyktatorskich rządów po zabójstwie Giacomo Matteotiego. Można by się w tym kontekście zastanawiać, czy po 1925 r. Italia wkroczyła już na drogę budowy ustroju totalitarnego, czy tylko autorytarnego. Co prawda książka Kiwior-Filo bezpośrednio nie dotyczy tej kwestii, lecz niewątpliwie jest to ważny problem badawczy, wywołujący spore kontrowersje wśród uczonych ${ }^{10}$. Jak wynika z trafnych wywodów Kiwior-Filo, włoscy liberałowie nie byli w tamtym okresie jednoznacznie negatywnie nastawieni do faszyzmu, a nawet nie dostrzegali w nim poważnego zagrożenia dla demokratycznych reguł polityczno-prawnych $w$ ramach ustroju monarchicznego w Italii. Co więcej: przynajmniej niektórzy z nich (m.in. B. Croce) spodziewali się, że Mussolini wraz ze swoimi akolitami zażegna niebezpieczeństwo rozwoju tendencji skrajnie lewicowych w Italii, stwarzając warunki do ustabilizowania sytuacji politycznej targanej po I wojnie światowej częstymi kryzysami władzy państwowej. Niektórzy liberałowie łudzili się nawet, że faszyści przyczynią się w związku z tym do umocnienia pozycji Włoch na arenie międzynarodowej. Dość wnikliwe rozważania na ten temat Kiwior-Filo opiera na analizie poglądów wyrażanych przez takich liberałów, jak Lugi Albertini, Giovanni Amendola, Benedetto Croce i Piero Gobetti.

Jeszcze bardziej rozbudowane są jej wywody zawarte w kolejnym rozdziale monografii, a dotyczące stosunku włoskich liberałów do faszyzmu już w okresie narastania totalitaryzmu (1925-1943). Na stronach rozprawy Kiwior-Filo pojawiają się w tym kontekście kolejne nazwiska myślicieli liberalnych: Guida De Ruggiero, Luigiego Einaudiego, Guglielma Ferrero i Francesca Saverio Nittiego. Wszyscy oni (oraz omawiany w tym fragmencie Croce) wykazywali coraz większy krytycyzm wobec rządów faszystowskich, wysu-

${ }^{10}$ Nie miejsce w tym artykule na rozwinięcie owej problematyki, o co już przed laty spierali się m.in. H. Arendt i K. Popper. Ta pierwsza uczona nie uważała - w odróżnieniu od Poppera i wielu innych badaczy - włoskiego faszyzmu za system w pełni totalitarny jak III Rzesza i Związek Sowiecki. Ostatnio nawiązał do tej kwestii w wydanej w Polsce (Warszawa 2015) książce Mussolini. Butny faszysta szwedzki autor G. Hägg. 
wając w swej ocenie tej dyktatury argumenty typowe dla liberalnego sposobu myślenia, a zatem gwałcenie przez Mussoliniego praw i wolności obywatelskich, deptanie reguł praworządności, totalizację życia publicznego, budowanie zrębów państwa korporacyjnego o elementach socjalistycznych, z reguły brutalne zwalczanie przejawów niezadowolenia społecznego z władzy faszystowskiej itp. Nic też dziwnego, że liberałowie z zadowoleniem przyjęli upadek dyktatury Mussoliniego w 1943 r., z niecierpliwością oczekując również na kres podjętego przez niego po tym fakcie eksperymentu politycznoustrojowego pod nazwą Republika Salo. Gdy i on się nie powiódł, niezupełnie słusznie uznali, że faszyzm się już ostatecznie skończył. Nieco na wyrost sobie samym przypisywali pewne zasługi w doprowadzeniu do upadku tego ustroju. Za Kiwior-Filo należy jednak powtórzyć, że włoscy liberałowie nie stanowili realnego zagrożenia dla faszystowskiego reżimu we Włoszech. Przeciwnie: byli oni jako intelektualiści zbyt słabi, by móc się jemu skutecznie przeciwstawić. W odróżnieniu od opozycjonistów dyktatury hitlerowskiej w III Rzeszy w zasadzie nie dotknęły ich - co warto zaznaczyć - szczególne represje ze strony władz faszystowskiej Italii. A swoją drogą: szkoda, że autorka nie zamieściła w swej rozprawie choćby krótkiego fragmentu na temat stosunku faszystów do rodzimych liberałów ${ }^{11}$. Bez większych przeszkód włoscy liberałowie mogli wtedy głosić swoje polityczne poglądy. Wiele diagnoz stawianych przez nich w odniesieniu do genezy, istoty i celów faszyzmu należy zresztą uznać za trafne, a co najmniej niepozbawione cech słuszności, jak np. opinia o tkwiących w kryzysie kulturowo-cywilizacyjnym po I wojnie światowej przyczynach popularności tego ruchu społeczno-politycznego, podobnie zresztą jak nazizmu w Niemczech.

Kilka słów należy się o bazie literaturowej i źródłowej omawianej monografii: niewątpliwie jest ona pokaźna, choć zabrakło w niej materiałów archiwalnych, co uważam za wyraźne uchybienie. Nie chce mi się wierzyć, by nie zachowały się żadne źródła archiwalne na prezentowany temat, np. opinie władz faszystowskich o włoskich liberałach. Można natomiast przypuszczać, że Kiwior-Filo wykorzystała jeśli nie wszystkie, to niemal wszystkie publikacje włoskich liberałów z pierwszej połowy XX w., bezpośrednio czy pośrednio odnoszące się do tamtejszego faszyzmu. Obszerna jest także spożytkowana przez autorkę literatura naukowa, przede wszystkim włoska, choć nie tylko taka. Ze zdziwieniem zauważyłem jednak, ż Kiwior-Filo nie sięgnęła do pionierskiej w Polsce, wydanej już niemal 30 lat temu książki Marii Zmierczak o sporach na temat faszyzmu ${ }^{12}$. A przecież omawiana mo-

${ }^{11}$ Głosząc koncepcje antyliberalne, włoscy faszyści - wśród których nie zabrakło grupy intelektualistów (G. Gentile, G. Bottai, A. Rocco, C. Costamagna i in.) - z istoty swego światopoglądu musieli być krytycznie nastawieni do liberalizmu, co w polskiej literaturze wykazał W. KozubCiembroniewicz w powołanych już publikacjach.

${ }^{12}$ M. Zmierczak, Spory o istotę faszyzmu. Dzieje i krytyka, Poznań 1988. 
nografia dotyczy właśnie interpretacji faszyzmu, wprawdzie dokonywanych tylko przez jeden nurt ideowy, ale mający przecież co najmniej kilku przedstawicieli, którzy niewątpliwie wnieśli ważny wkład do poznania sedna tego zjawiska. Przy okazji: krakowska badaczka powinna była wskazać, choćby w zakończeniu rozprawy, czym wyróżniała się - na tle innych interpretacji faszyzmu w Italii (m.in. przez A. Gramsciego) - jego egzegeza właśnie przez włoskich liberałów. Dzięki temu potencjalny czytelnik mógłby otrzymać pewne informacje, pozwalające spojrzeć na włoski liberalizm również w skali porównawczej.

II. Drugą współczesną krakowską badaczką włoskiego faszyzmu jest Joanna Sondel-Cedarmas, adiunkt z habilitacją w Katedrze Kultury i Społeczeństwa Europy w Instytucie Europeistyki Uniwersytetu Jagiellońskiego. Od czasu ukończenia w 2005 r. studiów doktoranckich na tej uczelni, a nawet jeszcze wcześniej dała się ona poznać jako coraz bardziej dojrzała intelektualnie badaczka, potrafiąca klarownie i przekonująco formułować tezy i wnioski naukowe $^{13}$. Nie ma w tym wszakże nic dziwnego, skoro dorastała w zasłużonej dla rozwoju nauki krakowskiej szkole historyków doktryn politycznych, która kształtowała się pod przemożnym wpływem najpierw profesorów Konstantego Grzybowskiego i Marka Sobolewskiego, a następnie m.in. profesorów Wiesława Kozuba-Ciembroniewicza i Bogdana Szlachty. Świetne przygotowanie intelektualne Sondel-Cedarmas wyniosła również z domu rodzinnego, zwłaszcza za sprawą swego ojca - profesora prawa rzymskiego. Od samego początku swej aktywności naukowej wykazywała się ona - co chcę podkreślić - nieczęstą u młodych nauczycieli akademickich umiejętnością posługiwania się literacko pięknym językiem polskim. Można przyjąć, że tak samo wypada ocena jej znajomości drugiego, podstawowego języka publikacji, czyli języka włoskiego. Bez doskonałej znajomości tego języka zapewne nie mogłaby swobodnie poruszać się w podejmowanej przez siebie problematyce badawczej. Z wykształcenia jest przecież filologiem włoskim nie tylko po studiach w Polsce (Uniwersytet Jagielloński), ale także we Włoszech (Uniwersytet $\mathrm{w}$ Udine). Z tą i innymi włoskimi uczelniami wyższymi (m.in. w Rzymie, Padwie i Trieście) ta młoda uczona utrzymuje do dzisiaj ożywione kontakty naukowe. W latach 2006-2007 była tzw. profesorem kontraktowym na Uniwersytecie w Udine. Na tej uczelni prowadziła także zajęcia dydaktyczne z kilku przedmiotów.

Na uniwersytetach w Krakowie i Udine Joanna Sondel-Cedarmas uzyskała dyplom magistra (lub jego odpowiednik) na podstawie rozpraw o poecie, pisarzu, dramaturgu i polityku Gabrielu D'Annunzio. Nie były to przy tym

13 Mogę to jednoznacznie stwierdzić, gdyż niejednokrotnie miałem okazje przysłuchiwać się wygłaszanym przez nią referatom i recenzować jej większe i mniejsze publikacje naukowe. 
dwie takie same prace magisterskie, gdyż na uczelni w Udine przedstawiła ujęcie jego twórczości w aspekcie polskim. D’Annunzia dotyczyła również jej rozprawa doktorska, o której będzie jeszcze mowa ${ }^{14}$. W tym miejscu dodam tylko, że został on w niej tym razem przedstawiony jako jeden $\mathrm{z}$ inspiratorów włoskiego faszyzmu. Już w tym miejscu przypomnę, że D’Annunzio stworzył po I wojnie światowej w Fiume (Rijeka) parafaszystowski system władzy, na którym częściowo wzorował się następnie Mussolini, nieodnoszący się zresztą ze szczególną atencją do tego nacjonalistycznego intelektualisty ${ }^{15}$. Wracając do tematyki naukowych dociekań Sondel-Cedarmas: co prawda akcenty badawcze zostały w każdej z tych 3 prac rozłożone nieco inaczej, wciąż jednak głównym tematem badawczym pozostawały poglądy, twórczość i działalność tego samego intelektualisty, czyli D'Annunzia. W ten sposób został on chyba nazbyt „wyeksploatowany” przez krakowską autorkę. Nie czynię jej z tego powodu wyraźnego zarzutu. Czuję się jednak w obowiązku wyrazić taką opinię, zwłaszcza że temu włoskiemu poecie poświęciła ona jeszcze co najmniej kilka drobniejszych rozpraw naukowych, które ukazały się drukiem nie tylko przed wydaniem wspomnianej pracy doktorskiej ${ }^{16}$. Już wtedy krakowska badaczka śmiało wkroczyła na obszar badawczy, którego zresztą nie opuściła do dzisiaj, gdyż wciąż stanowi on jeden z głównych przedmiotów jej naukowych zainteresowań. Jest nim nowsza i najnowsza ideologia oraz kultura polityczna we Włoszech, a szczególnie doktryna faszystowska oraz nacjonalistyczna. Naukowe osiągnięcia Sondel-Cedarmas w tej dziedzinie sytuują ją w gronie nielicznym zresztą w Polsce - najlepszych znawców rzeczonej problematyki badawczej, a więc wśród takich uczonych, jak wspomniani W. Kozub-Ciembroniewicz i J.W. Borejsza oraz M. Kiwior-Filo, a w dawniejszym okresie także już wspomniany S. Sierpowski.

Dobrze się zatem stało, że Sondel-Cedarmas zajęła się przed kilkoma laty wymienionymi zagadnieniami badawczymi, w tym właśnie włoskim faszyzmem. Bez opracowania jego ideowych korzeni i założeń oraz przejawów w życiu politycznym, społecznym i kulturalnym nie byłoby bowiem możliwe kompleksowe ujęcie w polskiej literaturze naukowej szerszej problematyki totalitaryzmu w XX w. Choć nie wszyscy autorzy uważają - jak już pisałem - faszyzm w Italii za rodzaj totalitaryzmu, a jedynie za system autorytarny, na ogół są jednak zgodni w kwestii oceny tego faszyzmu jako doktryny i ustroju

14 J. Sondel-Cedarmas, Gabriele D'Annunzio. U źródel ideologicznych włoskiego faszyzmu, Kraków 2008, ss. 317.

15 Ostatnio kwestię relacji między tymi politykami dokładnie przedstawił G. Hägg w książce Mussolini. Butny faszysta (Warszawa 2015), o której już pisałem w tym artykule recenzyjnym.

${ }^{16}$ Przykładowo opublikowała ona w „Studiach nad Faszyzmem i Zbrodniami Hitlerowskimi” artykuły: Gabriele D'Annunzio a system polityczny Fiume (1919-1920) (t. XXVI, 2003); Elitaryzm, nacjonalizm, imperializm w myśli politycznej Gabriele D'Annunzia (t. XXVIII, 2005); Myśl polityczna Gabriela D'Annunzia wobec rozwoju faszyzmu we Włoszech (1921-1938) (t. XXVIII, 2005); Koncepcje nadczłowieka Gabriela D'Annunzio (t. XXIX, 2007). 
o cechach antyliberalnych, antydemokratycznych i dyktatorskich. Należy zaznaczyć, że nie wszystkie aspekty tego zjawiska doczekały się już wyczerpującego omówienia w polskiej literaturze naukowej. Przed Sondel-Cedarmas, jak i przed Kiwior-Filo otwierają się zatem wciąż nowe możliwości badawcze w tej dziedzinie. Mam nadzieję, że właściwie spożytkują one swój znaczny potencjał intelektualny, podejmując kolejne naukowe poszukiwania i wyzwania nie tylko zresztą w temacie ,włoski faszyzm”. Warto by np. spenetrować pokrewny obszar badawczy, słabo opracowany naukowo w Polsce, a mianowicie neofaszyzm w Italii czy tamtejszą Nową Prawicę, w tym źródła ideologiczne i założenia doktrynalne tych ugrupowań. W ten sposób Sondel-Cedarmas czy Kiwior-Filo mogłyby niejako zmonopolizować - w pozytywnym znaczeniu tego słowa - rzeczoną problematykę. Jak mi wiadomo, Sondel-Cedarmas podjęła już (z pozytywnym skutkiem) odnośne badania naukowe ${ }^{17}$. Warto w tym miejscu zauważyć, że na kompleksowe opracowanie w naszym kraju oczekują również faszyzmy w innych niż Włochy państwach. Dobry początek takim badaniom dał ceniony znawca myśli politycznej krajów romańskich Adam Wielomski, który zajął się zaniedbaną w polskiej literaturze problematyką faszyzmu francuskiego, hiszpańskiego i portugalskiego ${ }^{18}$. Póki co nie zostało jednak wypowiedziane przez tego uczonego ostatnie słowo w tych kwestiach naukowych. Przypomnę, że zjawiska polityczne o charakterze faszystowskim lub parafaszystowskim powstały i rozwijały się w okresie międzywojennym również w takich krajach, jak Szwecja, Norwegia i Finlandia, Belgia i Holandia, Węgry, Bułgaria i Rumunia. Nie ulega wątpliwości, że ta problematyka także zasługuje - m.in. ze względu na swoje odniesienia do faszyzmu włoskiego czy niemieckiego nazizmu - na pogłębione badania naukowe w Polsce.

Jak już wskazałem, jednym z głównych wątków badawczych przewijających się w naukowej twórczości omawianej autorki, w szczególny sposób charakteryzujących jej naukową sylwetkę, jest faszyzm i nacjonalizm w Italii od schyłku XIX w. do końca II wojny światowej. To z tej niezmiernie ciekawej, ale niełatwej do opracowania problematyki - wymagającej bowiem nie tylko studiowania odnośnej literatury, ale również licznych materiałów źródłowych - opublikowała ona najważniejsze w swym dorobku naukowym rozprawy: doktorską i habilitacyjną. Zanim przejdę do ustosunkowania się do nich,

${ }^{17}$ Na międzynarodowej konferencji naukowej w Wilnie w kwietniu 2014 r. przedstawiła referat Eurosceptycyzm skrajnej prawicy na przykładzie włoskich ugrupowań neofaszystowskich, a na kongresie politologicznym w Krakowie we wrześniu 2015 r. referat Od Europrawicy do Nowej Prawicy - próba odnowy ideowej Wtoskiego Ruchu Społecznego w latach 70-tych i 80-tych XX wieku.

18 A. Wielomski, Faszyzmy tacińskie. Sen o rewolucji innej niż w Rosji i w Niemczech, Arte Klub Zachowaczo-Monarchistyczny, b.m.w., b.r.w. Częściowo o tę problematykę zahacza obszerna monografia J. Bartyzela „,Umierać, ale powoli”. O monarchistycznej i katolickiej kontrrewolucji w krajach romańskich 1815-2000, Kraków 2002. 
wskażę na co najmniej jeszcze dwa obszary naukowych penetracji SondelCedarmas, przeradzających się nierzadko w fascynację określonym tematem. Jeden z nich stanowi problematyka holokaustu włoskich Żydów od końca lat trzydziestych do połowy lat czterdziestych XX w., wiążąca się z zainteresowaniami krakowskiej uczonej w ogóle faszyzmem i świadcząca o poszerzeniu przez nią w ostatnim okresie swych wcześniejszych badań w tej dziedzinie. Na wskazany temat Sondel-Cedarmas opublikowała dotychczas jeden artykuł w renomowanym piśmie naukowym Wydziału Studiów Międzynarodowych i Politycznych Uniwersytetu Jagiellońskiego „Politeja”19. Jak mi wiadomo, ma ona ambitne plany naukowe dotyczące szerszego, bardziej kompleksowego opracowania wskazanej problematyki. Byłoby to tym bardziej wskazane, że w literaturze naukowej włoscy faszyści uchodzą za znacznie mniej ,żydożerczych" od niemieckich narodowych socjalistów, co zresztą wydaje się generalnie rzecz ujmując - zgodne z prawdą. Niemniej jednak, także w Italii Mussoliniego, wprowadzono w latach trzydziestych XX w. i stosowano antyżydowskie, i w ogóle rasistowskie prawodawstwo, wzorowane na odnośnych regulacjach prawnych przyjętych w III Rzeszy. Nadmienię, że niedawno problematyce tej poświęcił dwa artykuły wspomniany P. Podemski, które zostały opublikowane w „Studiach nad Autorytaryzmem i Totalitaryzmem"20.

Po raz kolejny zaznaczę, że zainteresowania naukowe J. Sondel-Cedramas od kilkunastu lat koncentrują się na dwóch głównych zagadnieniach badawczych: włoskim faszyzmie i nacjonalizmie, które zresztą wyraźnie przeplatają się ze sobą. Na pierwszy z wymienionych tematów wydała ona drukiem kilka drobniejszych tekstów naukowych i wspomnianą monografię książkową o D’Annunzio, będącą rozwinięciem rozprawy doktorskiej. Wśród artykułów autorstwa krakowskiej uczonej z problematyki faszyzmu w Italii moją uwagę - prócz artykułów o tym poecie i polityku - zwróciło opracowanie dotyczące ideologicznych inspiracji wybitnego elitarysty włoskiego Vilfreda Pareto wobec doktryny włoskiego faszyzmu ${ }^{21}$. Choć ten myśliciel zmarł już w 1923 r., nie doczekawszy przekształcenia faszyzmu w system rządów dyktatorskich, niezupełnie zresztą zgodnych z jego wizją elitaryzmu, to jednak faszyści w Italii nawiązywali do niego w swych koncepcjach ustrojowych. Zupełnie nie występowały natomiast takie odniesienia $\mathrm{w}$ przypadku poglądów politycznych kolejnego z omówionych przez Sondel-Cedarmas intelektualisty włoskiego - komunisty Antonio Gramsciego. Uważali oni bowiem

19 J. Sondel-Cedarmas, Giovanni Preziosi i Generalny Inspektorat do Spraw rasowych (1944-1945), „Politeja”, 2013, t. XXIII, s. 193 i n.

${ }^{20}$ Chodzi o artykuły Faszyzm włoski wobec kwestii żydowskiej1919-1938 (2012, t. 34, nr 1, s. 81 i n.) oraz Prawna i faktyczna sytuacja włoskich Żydów w dobie prześladowań faszystowskich 1938-1943 (2013, t. 35, nr 3, s. 7 i n.)

${ }^{21}$ J. Sondel-Cedarmas, Myśl polityczno-prawna i ustrój włoskiego faszyzmu a inspiracje ideologiczne Vilfredo Pareto, [w:) Egalitaryzm i elitaryzm. Tradycja i przyszłość Europy, red. E. Kozerska, P. Sadowski i A. Szymański, Opole 2012, s. 251 i n. 
tego myśliciela - podobnie jak w ogóle skrajną lewicę - za wroga faszyzmu, zwalczając ją nie tylko w sferze ideologicznej. Ze swej strony to samo starał się wobec faszyzmu czynić (głównie w sferze werbalnej) Gramsci, przebywający w okresie dyktatury Mussoliniego w areszcie domowym. Nie przeszkadzało to i jednemu, i drugiemu odwoływać się - z odmiennych pozycji doktrynalnych - do tych samych koncepcji dyktatury księcia Niccola Machiavellego. Nader krytycznemu stosunkowi Gramsciego do włoskiego faszyzmu krakowska autorka poświęciła przed kilkoma laty jeden ze swych artykułów $^{22}$. Czytelnik znajdzie w obu tych tekstach - potwierdzających znaczną wiedzę i erudycję Sondel-Cedarmas - nie tylko sporo ciekawych informacji, ale również wiele trafnych spostrzeżeń badawczych. Nie wszystkie wyrażone przez nią opinie wydają się jednak w pełni odkrywcze, gdyż podjęta w tych artykułach problematyka była już wcześniej przedmiotem analizy naukowej, głównie w literaturze zagranicznej.

Niewątpliwie najważniejszym osiągnięciem Sondel-Cedarmas - przed opublikowaniem książki o włoskim nacjonalizmie - w dziedzinie badań nad szeroko rozumianą problematyką włoskiego faszyzmu jest jej monografia o D’Annunziu. Książką tą wypełniła ona wyraźną lukę w polskiej literaturze naukowej dotyczącą ideowych korzeni tego faszyzmu. Śmiało mogę stwierdzić, że monografia o tym poecie i polityku jest niemal znakomitym opracowaniem naukowym, choć mogącym budzić pewne kontrowersje (o czym niżej). Krakowska badaczka znacznie przybliżyła w swojej monografii polskiemu czytelnikowi postać D’Annunzia, raczej mało znaną w naszym kraju, a bezsprzecznie zasługującą na przypomnienie. Nie był to bowiem tuzinkowy poeta, pisarz, dramaturg i polityk o nacjonalistycznej orientacji w jednej osobie, lecz przeciwnie - intelektualista ważny w ogóle dla duchowego rozwoju Włoch na przełomie XIX i XX w. Lektura książki Sondel-Cedarmas dostarcza o nim - w moim przekonaniu - nie tylko wiele ciekawych informacji, ale skłania również do refleksji nad nowszymi dziejami literatury pięknej w bliskiej polskiej kulturze Italii. Autorce zapewne dopomogło w tym jej filologiczne wykształcenie w połączeniu z posiadanym przez nią odpowiednim przygotowaniem politologicznym. Dodam, że na styku tych dwóch dyscyplin wiedzy mieszczą się także inne teksty naukowe Sondel-Cedarmas, co pozwala jej spoglądać na prezentowaną problematykę badawczą z szerszej perspektywy intelektualnej, uwzględniając dokonania i aparaturę pojęciową tak nauk humanistycznych, jak i społecznych.

Uczona z Uniwersytetu Jagiellońskiego postawiła w książce o D’Annunziu sporo naukowo doniosłych tez, które z pozytywnym skutkiem starała się udowodnić, przeprowadzając właściwą dedukcję. Warto zatem zwrócić uwagę

${ }^{22}$ Eadem, Antonio Gramsci wobec włoskiego faszyzmu, [w:] Totalitaryzmy XX wieku. Idee instytucje - interpretacje, red. W. Kozub-Ciembroniewicz, H. Kowalska-Stus, B. Szlachta i M. Kiwior-Filo, Kraków 2011, s. 203 i n. 
na kilka najistotniejszych spośród nich. Przede wszystkim rozprawia się ona (a przynajmniej usiłuje to uczynić) z rozpowszechnioną w literaturze naukowej opinią, według której D’Annunzio był prekursorem włoskiego faszyzmu. Nie ukrywam, że również do mego przekonania przez lata trafiał taki pogląd. Według Sondel-Cedarmas owo twierdzenie nie jest natomiast zupełnie słuszne, gdyż poeta ten ulegał inspiracji ze strony różnych ideologii, a jego polityczne koncepcje ewoluowały od końca XIX w. do czasu śmierci w 1938 r., bynajmniej nie wyłącznie w kierunku faszyzmu, a nawet niekiedy w pewnej opozycji do niego. Niewątpliwie wywarł on jednak - obstawałbym przy tym sądzie - wpływ (częściowo niezamierzony) na kształtowanie się teorii i praktyki faszyzmu w Italii, podobnie jak np. niektórzy rewolucyjni konserwatyści w Republice Weimarskiej oddziaływali swymi politycznymi koncepcjami na nazizm, choć bywali krytycznie nastawieni do niego. Czy można w związku z tym obciążać tego poetę, pisarza i dramaturga bezpośrednio odpowiedzialnością za ukształtowanie się faszyzmu? Także według mnie nie należy wyraźnie wskazywać na taką korelację. Sondel-Cedarmas nieprzypadkowo jednak użyła w podtytule swej książki słowo „źródła” w odniesieniu do ideologii włoskiego faszyzmu, co sugeruje przyjęcie określonego założenia badawczego przy omawianiu poglądów D’Annunzia. Wskutek tego popadła w swego rodzaju terminologiczną pułapkę. Została bowiem zmuszona do dokonania niełatwego rozgraniczenia takich pojęć, jak „,́ródło”, „,inspiracja”, „wpływ” czy „prekursorstwo"23. Wydaje się, że Sondel-Cedarmas nieco się w tym wszystkim pogubiła. Na s. 261 nie zgadza się bowiem na uznanie D’Annunzia za prekursora faszyzmu, kilka stron dalej (s. 264) wycofuje się z tego stanowiska, choć czyni w tym zakresie pewne zastrzeżenia. Ostatecznie przyjmuje tezę, że tego intelektualisty i polityka nie można jednoznacznie określić jako faszystę. W celu uzasadnienia tej opinii przytacza rozmaite przykłady z jego twórczości i działalności. Wiele z nich rzeczywiście wydaje się trafnych.

Kwestia uznania D’Annunzia za prekursora faszyzmu, a nawet za jego przedstawiciela stanowi jeden z najważniejszych, a przy tym kontrowersyjnych problemów naukowych omówionych przez Sondel-Cedarmas. Nie wyczerpuje jednak - i słusznie - tematyki jej książki. W kompleksowy i kompetentny sposób została bowiem w niej przedstawiona w zasadzie cała biografia tego intelektualisty i polityka, choć z wyraźnym ukierunkowaniem na sprawy dotyczące źródeł włoskiego faszyzmu. Dowiadujemy się z niej, że wpływ na poglądy D'Annunzia wywarły rozmaite, niekoniecznie pokrewne sobie koncepcje, np. filozofia Hegla, Nietzschego i Schopenhauera, idea tzw. trzeciego Rzymu Giuseppe Mazziniego, wreszcie myśl Risorgimento. Jako nacjonalista był on jeszcze przed wybuchem I wojny światowej rzecznikiem idei mocar-

${ }^{23}$ Zwróciłem uwagę na te kwestie terminologiczne w swojej recenzji dorobku naukowego dr M. Sondel-Cedarmas w związku z ubieganiem się przez nią o uzyskanie stopnia naukowego doktora habilitowanego. 
stwowości Włoch wzorowanej na starożytnym imperium rzymskim i mającej realizować się przez wybitnych przywódców, którzy powinni w tym celu posługiwać się metodami antydemokratycznymi, a nawet siłą zbrojną ${ }^{24}$. Takie poglądy mogły - co trzeba przyznać - trafiać do politycznego ,gustu” faszystów, choć nie były głoszone z myślą o Mussolinim i jego akolitach. Należy podkreślić, że wiele $\mathrm{z}$ tych koncepcji D’Annunzio sformułował jeszcze przed powstaniem po I wojnie światowej faszyzmu w Italii.

Propaganda faszystowska mogła także wykorzystać dla swych nacjonalistycznych i imperialistycznych celów (nie pytając tego intelektualistę i polityka o zgodę) słynną, zakończoną sukcesem akcję militarną podjętą przez niego w 1919 r. z zamiarem przyłączenia do Włoch spornego obszaru wokół Fiume (Rijeki). Zdobycie tego niewielkiego terytorium i zaprowadzenie na nim rządów quasi-faszystowskich traktowane było po 1919 r. - o czym dokładnie pisze Sondel-Cedarmas - przez władze faszystowskie jako ,poligon doświadczalny" dla późniejszych przeobrażeń ustrojowych w Italii oraz podbojów dokonywanych przez nie w Europie i Afryce w latach trzydziestych i czterdziestych XX w. Faszystom marzyło się - podobnie jak D’Annunzio uczynienie z Morza Śródziemnego ,wewnętrznego morza” włoskiego (Mare Nostrum). W trafnej opinii krakowskiej badaczki z faszystami łączyły tego poetę i pisarza wspólne źródła patriotyczno-nacjonalistyczne, mit kombatanta I wojny światowej, zasada wodzostwa, idea korporacyjna, a nawet jego pomysł zorganizowania marszu na Rzym w celu objęcia władzy w całej Italii, wcześniejszy zresztą od urzeczywistnienia tej koncepcji przez bojówki Mussoliniego pod koniec 1922 r. Przykładów duchowego pokrewieństwa D’Annunzia i faszyzmu można by za autorką podać jeszcze więcej. Jego przypadek przypomina trochę sytuację niemieckiego filozofa Oswalda Spenglera, a chyba jeszcze bardziej prawnika Carla Schmitta (zaliczanych do wspomnianego grona rewolucyjnych konserwatystów), którzy mieli ambiwalentny stosunek do nazizmu, co nie przeszkadzało Adolfowi Hitlerowi czy innym narodowosocjalistycznym propagandystom wybiórczo korzystać, m.in. z koncepcji tych dwóch intelektualistów ${ }^{25}$. Już ten pobieżny przegląd treści omawianej monografii wyraźnie wskazuje, że zawarte w niej wywody zostały w znaczniej mierze zdominowane przez kwestię relacji D’Annunzio - faszyzm. Trudno się zresztą temu dziwić, skoro takie było główne założenie badawcze przyjęte przez Sondel-Cedarmas.

Uwieńczeniem dotychczasowego rozwoju naukowego badaczki z Uniwersytetu Jagiellońskiego - wyraźnie już ukierunkowanego na problematykę

24 Prócz Sondel-Cedarrmas szerzej o tym pisze m.in. M. Cagnetta, Idea di Roma, colonialismo e nazionalismo nell'opera di D'Annunzio, [w:] D'Annunzio e il classicism, „Quaderni del Vittoriale", 1980, t. XXIII.

25 Przed laty pisałem o tym w książce Niemieckie elity a hitleryzm. O stosunku rewolucyjnych konserwatystów do nazizmu w Rzeszy demokratycznej i hitlerowskiej (Wrocław 1994). 
faszyzmu - jest jej rozprawa habilitacyjna z 2013 r. o włoskim nacjonalizmie. Obejmuje ona niemal trzydziestoletni okres kształtowania się tej doktryny - od schyłku XIX w. do początków władzy faszystowskiej w Italiii ${ }^{26}$. Do mego przekonania trafia tak wewnętrzna struktura tej książki, oparta na kryterium chronologiczno-problemowym, jak i sposób oraz zakres prezentacji jej problematyki, a także przyjęta metoda badawcza, nie mówiąc już o samym warsztacie naukowym. Opublikowanie tej liczącej niemal 500 stron, składającej się z 15 rozdziałów i opartej na szerokiej bazie źródłowej (prasa i archiwa włoskie) oraz na licznej literaturze monografii poprzedził cykl drobniejszych tekstów na ten temat. Już w tym miejscu pragnę zauważyć, że książka o włoskim nacjonalizmie jest pionierskim opracowaniem w polskiej literaturze naukowej. Żaden inny autor przed Sondel-Cedarmas nie wydał drukiem w naszym kraju tak obszernej i kompleksowej monografii dotyczącej tej rozległej i zapewne niełatwej problematyki. Krakowska badaczka rzeczywiście stanęła przed trudnym zadaniem badawczym, które polegało na udzieleniu odpowiedzi na wiele istotnych kwestii, dysponując w tym celu nierzadko jedynie własnymi przemyśleniami. Również w zagranicznej literaturze podjęty przez nią temat nie został bowiem dogłębnie opracowany, choć niewątpliwie lepiej niż w polskiej ${ }^{27}$. Za trafny należy zatem uznać sam wybór problematyki włoskiego nacjonalizmu, wskutek czego wypełniona została poważna luka w polskiej literaturze naukowej. Od razu dodam: luka odnosząca się w dużej mierze do kwestii pełniejszego poznania ideologicznych źródeł faszyzmu w Italii. W tym sensie omawiana rozprawa habilitacyjna wskazuje na kontynuację przez autorkę zapoczątkowanych przez nią przed laty badań nad doktrynalną genezą tamtejszego faszyzmu, stanowiącą differentia specifica jej zainteresowań naukowych i czyniącą z niej niekwestionowaną znawczynię tych zagadnień. Z tego względu książkę Sondel-Cedarmas o D'Annunziu można potraktować jako zapowiedź jeszcze bardziej od tej pierwszej merytorycznie kompleksowej monografii o nacjonalizmie w Italii, zawierającej zresztą liczne odniesienia do D'Annunzia. Rzecz jasna, omawiana rozprawa habilitacyjna bynajmniej nie wyczerpuje całej problematyki źródeł włoskiego faszyzmu.

O zasadności wyboru tematyki nacjonalizmu - mimo że odnosi się ona do Włoch sprzed niemal 100 lat - świadczy także jej aktualny wydźwięk polityczny. Całe niemal XX stulecie stało bowiem pod znakiem rozwoju nacjonalizmu - szczególnie od lat dwudziestych do lat czterdziestych - który okazał się zgubny i tragiczny w skutkach nie tylko w przypadku Italii pod rządami faszystów czy Niemiec pod rządami nazistów. Niemały wpływ wy-

26 J. Sondel-Cedarmas, Nacjonalizm wloski. Geneza i ewolucja doktryny politycznej (1896-1923), Kraków 2013, ss. 481.

27 Zob. F. Gaeta, Il nazionalismo italiano, Roma-Bari 1981; F. Perfetti, Il nazionalismo italiano dalle origini alla fusion col fascismo, Bologna 1977; S. Lanaro, Nazionalismo e ideologia del blocco corporativo-protezionista in Italia, „Ideologie”, 1967, $\mathrm{nr} 2$. 
warła owa doktryna na kształtowanie się koncepcji politycznych także m.in. we Francji od końca XIX w. do czasów bardziej współczesnych, co zasadnie wykazał przed kilkoma laty wspomniany A. Wielomski ${ }^{28}$. Na nacjonalizmie bazują również powojenni neofaszyści i neonaziści oraz ideowo pokrewne im ugrupowania polityczne. Przypomnę, że jeszcze pod koniec ubiegłego wieku nacjonalizm dał o sobie znać - z jak najgorszej strony - na obszarze byłej Jugosławii. Wiadomo, że współcześnie w Europie wciąż występują tendencje nacjonalistyczne, niekiedy w połączeniu z dążeniami separatystycznymi (Baskowie, Katalończycy, Walonowie, Flamandowie, Szkoci, Walijczycy i in.). Od nacjonalizmu, a nawet ksenofobii, nie są wolne uważane za przyjazne obcym Niemcy czy Francja, co uwidacznia się np. w związku z problemem społecznej i kulturalnej adaptacji mas imigrantów, zwłaszcza o pochodzeniu arabskim. Z poważnymi konsekwencjami (walki zbrojne, rzezie ludności cywilnej, grabieże mienia itp.) narastania rozmaitych nacjonalizmów mamy obecnie do czynienia także poza naszym kontynentem, m.in. w Afryce. W kręgach liberalno-lewicowych w Polsce na początku XXI w. pokutuje opinia, że również w naszym kraju nasilają się tendencje nacjonalistyczne, a nawet faszystowskie. Na marginesie: nierzadko owe środowiska mylą przy tym nacjonalizm z patriotyzmem. Wszystko to potwierdza aktualność problematyki nacjonalizmu, który jako określona ideologia sięga swymi korzeniami do XIX stulecia, nie będąc zresztą wtedy powszechnie uważana przez wszelkiej maści progresywistów (jak to często bywa współcześnie) za zjawisko jednoznacznie negatywne. Przeciwnie - nacjonalizm odegrał w tamtym okresie w znacznej mierze pozytywną rolę, zwłaszcza w kształtowaniu się ruchów narodowo-wyzwoleńczych i w ogóle nowoczesnych narodów w Europie. Dobrze się zatem i z tego powodu stało, że Sondel-Cedarmas zajęła się tymi kwestiami badawczymi.

Przechodząc do meritum rozprawy habilitacyjnej: zawarte w niej wywody obejmują okres niemal 30 lat od będącej symbolem klęski i poniżenia Włoch bitwy pod Aduą w 1896 r. do połączenia Stowarzyszenia Nacjonalistów Włoskich z partią faszystowską w 1923 r. Należy zgodzić się z autorką, że był to najważniejszy przedział temporalny dla kształtowania się nacjonalizmu w Italii, poprzedzony powstaniem i rozwojem ruchu Risorgimento, bez którego trudno sobie wyobrazić narastanie na Półwyspie Apenińskim tendencji nacjonalistycznych, co powinno zresztą zostać bardziej wyeksponowane w omawianej monografii. W każdym razie przyjęte przez Sondel-Cedarmas cezury czasowe są niewątpliwie jak najbardziej właściwe. Nie ogranicza się ona wszakże w swych rozważaniach wyłącznie do okresu mieszczącego się po-

28 A. Wielomski, Nacjonalizm francuski 1886-1940. Geneza, przemiany i istota filozofii politycznej, Warszawa 2007. Jak mi wiadomo, monografia ta została wysoko oceniona przez wybitnego polskiego znawcę dziejów Francji i jej ideologii politycznych - prof. Jana Baszkiewicza. 
między obiema datami. Słusznie jej książkę otwiera rozdział traktujący o sporach wokół istoty włoskiego nacjonalizmu, odnoszący się także do czasów sprzed 1896 r. Na marginesie: tytuł tego fragmentu brzmi niemal identycznie (czy to przypadek?) jak tytuł wspomnianej w tym artykule recenzyjnym monografii Marii Zmierczak o sporach wokół faszyzmu. W rozdziale tym Sondel-Cedarmas przedstawia przynajmniej częściowo własny pogląd na nacjonalizm w ogóle, oponując przeciwko określaniu tym mianem każdej ideologii czy doktryny, która opiera się na eksponowaniu roli i znaczenia narodu ${ }^{29}$. Takie podejście do istoty nacjonalizmu (występujące niekiedy w literaturze anglosaskiej) trafnie uważa za zbyt duże uproszczenie intelektualne, prowadzące do wypaczenia sensu tej ideologii poprzez przyjęcie jej politycznie neutralnego rozumienia. Przy takim założeniu badawczym należałoby bowiem bez zastrzeżeń za proroka włoskiego nacjonalizmu uznać Giuseppe Mazziniego, a w Polsce pod zaborami np. Adama Mickiewicza. Jak więc powinno się interpretować istotę nacjonalizmu - zastanawia się krakowska badaczka. Dochodzi do słusznego wniosku, że była to (i w zasadzie jest nadal) doktryna, która zakładała podporządkowanie jednostki zbiorowości narodowej jako nadrzędnej wartości wyrastającej z tradycji i kultury, niosącej ze sobą potrzebę aktywności na jej rzecz, a nawet poświęcenia się dla jej dobra. Można zatem dostrzec - przynajmniej w niektórych przypadkach - pewne korelacje między nacjonalizmem i patriotyzmem. Takie pojmowanie nacjonalizmu nie wyklucza związków wartości narodowych z ideą demokratyczną czy hasłami postępu społecznego i wyzwolenia narodowego.

Od około lat siedemdziesiątych XIX w. zaczęło się jednak upowszechniać (na co zwrócił m.in. uwagę brytyjski historyk E.J.E. Hobsbawm) ujmowanie nacjonalizmu jako doktrynalnego wyrazu dążenia do rywalizacji między narodami, a nawet podboju jednych $\mathrm{z}$ nich przez drugie $\mathrm{w}$ celu osiągnięcia politycznej, gospodarczej czy militarnej przewagi w stosunkach międzynarodowych. Według tej koncepcji nacjonalizm nie byłby jedynie zaprzeczeniem idei współpracy pokojowej czy zasad demokratycznych, lecz przejawem daleko posuniętej konkurencji między narodami ${ }^{30}$. Za jej intelektualną podstawę mogły na przełomie XIX i XX w. służyć koncepcje elitaryzmu (we Włoszech rozwijane zwłaszcza przez wspomnianego Pareta i Gaetano Moscę), których autorzy uznawali za naturalne i oczywiste dla funkcjonowania narodu jego dążenie do górowania nad innymi nacjami. Stąd byłby już tylko krok do narastania tendencji imperialistycznych. Jak wiadomo, z całą siłą uwidoczniły się one podczas I wojny światowej i w późniejszym okresie. Niewątpliwą za-

29 Podobne ujęcie tej problematyki można znaleźć w wydanym także przez pracowników naukowych Uniwersytetu Jagiellońskiego - B. Grotta i O. Grotta - obszernym opracowaniu zbiorowym Nacjonalizmy różnych krajów. Perspektywa politologiczno-religioznawcza (Kraków 2012).

${ }^{30}$ Zob. E.J.E. Hobsbawm, Narody i nacjonalizm po 1780 roku, thum J. Maciejczyk i M. Starnawski, Warszawa 2010. W oryginale rozprawa ta ukazała się po angielsku w Cambridge w $1990 \mathrm{r}$. 
sługą Sondel-Cedarmas jest dostrzeżenie wskazanej złożoności, a nawet niuansów zagadnień składających się na kwestie nacjonalizmu. Autorka stanęła przed koniecznością uporania się dla potrzeb analizy podjętej problematyki badawczej z licznymi trudnościami terminologiczno-definicyjnymi związanymi z określeniem nacjonalizmu. Starając się z nich wybrnąć, przyjęła użyte już kiedyś przez J. Bartyzela pojęcie „,nacjonalitaryzm”, które wydaje się jednak kontrowersyjne, na co zresztą jeszcze przed opublikowaniem omawianej rozprawy habilitacyjnej zwrócił uwagę inny badacz doktryny nacjonalistycznej (na przykładzie Francji) - wspomniany A. Wielomski ${ }^{31}$. Osobiście opowiadałbym się za posługiwaniem się nie tylko w odniesieniu do Włoch przełomu XIX i XX w. po prostu określeniami „myśl (idea) narodowa”. Pozostając przy kwestiach terminologicznych: w nowszej i najnowszej literaturze naukowej (m.in. w publikacjach B. Grotta) występuje jeszcze jedno określenie, które odnosi się przede wszystkim do okresu międzywojennego, a mianowicie pojęcie „nacjonalizm integralny”32. Jak widać, niełatwo jest uporać z desygnatami pojęcia nacjonalizmu. Już samo podjęcie próby rozwikłania tej problematyki przez Sondel-Cedarmas należy więc odnotować pozytywnie. Jestem przekonany, że spory o istotę i elementy nacjonalizmu będą jeszcze długo trwać w nauce.

Po przedstawieniu rozważań nad pojęciem i treścią nacjonalizmu autorka przechodzi do omówienia bardziej szczegółowych kwestii składających się na problematykę jej monografii. Lektura tej książki dostarcza wielu ważnych informacji na temat historycznego podłoża, genezy, motywów i ewolucji nacjonalizmu we Włoszech. Nie ukrywam, że wszystkie jej fragmenty czytałem z dużym zaciekawieniem, a niekiedy nawet z zapartym tchem. Nie dostrzegam wszakże potrzeby dokładnego zaprezentowania w tym artykule recenzyjnym treści kolejnych rozdziałów. Jako badacza myśli politycznej i prawnej zainteresowały mnie zwłaszcza same koncepcje włoskich nacjonalistów kształtujące się w przełomowym - jak by nie było - okresie dziejów Italii od czasu zjednoczenia państw na Półwyspie Apenińskim do pierwszych lat po zakończeniu I wojny światowej. Sondel-Cedarmas z ogromnym znawstwem ukazała budowę zrębów doktryny włoskiego nacjonalizmu jako w miarę zwartego systemu myślowego, analizując najpierw idee jego prekursorów: Pasqualego Turiela, Giosuè Carducciego, Alfreda Orianiego, Maria Morraso, a także D’Annunzia. Z jej przekonujących wywodów wynika, że wszyscy oni

${ }^{31}$ Zob. powołaną już książkę A. Wielomskiego o francuskim nacjonalizmie oraz opracowanie zbiorowe pod red. J. Bartyzela i D. Góry-Szopińskiego, Nacjonalizm a konserwatyzm i monarchizm. Action Française i jej promieniowanie, Torun 2011.

${ }^{32} \mathrm{O}$ rosnącym zainteresowaniu badaczy różnorodnością problematyką nacjonalizmu świadczy coraz większa liczba publikacji na ten temat, a wśród nich monografia R. Brubakera, Nacjonalizm inaczej. Struktura narodowa i kwestie narodowe w nowej Europie, tłum. J. Łuczyński, Warszawa-Kraków 1998. 
byli przeciwnikami demokracji, parlamentaryzmu, liberalizmu i socjalizmu. Wszyscy oni pragnęli przy tym, by w zjednoczonej Italii żyli także zjednoczeni ze sobą solidarnymi więzami narodowymi Włosi, świadomi swojego wspaniałego dziedzictwa duchowego i kulturalnego oraz chlubnej tradycji, równocześnie gotowi do formułowania i realizowania dążeń i celów na przyszłość. Rozbudzenie świadomości narodowej pod koniec XIX w. i na początku XX w. nie było wszakże jedynie cechą niemałych zresztą kręgów ówczesnego społeczeństwa włoskiego, ale znamionowało również nastroje panujące w innych krajach europejskich. W szczególnie wyraźny sposób uwidoczniło się w Rzeszy Niemieckiej, gdzie nacjonalizm urastał niemal do rangi oficjalnej doktryny państwowej, wspartej częściowo na założeniach rasistowskiej ideologii volkistowskiej, z której obficie czerpali następnie naziści ${ }^{33}$. Jestem ciekaw, czy krakowska badaczka dostrzega pewne prawidłowości w rozwoju nacjonalizmu w Italii i innych krajach w tamtym okresie. Jak sądzę, można w tej dziedzinie wskazać i na podobieństwa, i na odmienności między nimi. Innymi słowy: w jakim zakresie nacjonalizm we Włoszech stanowił element szerszego zjawiska nacjonalizmu europejskiego? Niestety odpowiedzi na to ważne pytanie nie znajdzie się w rozprawie Sondel-Cedarmas.

Co się tyczy kolejnych fragmentów omawianej monografii: rozdział trzeci przynosi omówienie różnorodnego nacjonalizmu włoskiego w latach 19031910. Ukazuje on rzeczywiście rozmaite idee nacjonalistyczne (m.in. na przykładzie poglądów M. Viany) dotyczące konieczności przebudowy narodu i państwa włoskiego w pożądanym przez rzeczników tej doktryny kierunku. W osobnym, czwartym rozdziale zostały umiejętnie zanalizowane koncepcje jednego z najważniejszych twórców rzeczonej doktryny, głoszącego mit Wielkich Włoch, a zatem łączącego nacjonalizm z imperializmem - Enrica Corradiniego. Nieco zaskakujący wydaje się na ,pierwszy rzut oka” tytuł kolejnego rozdziału: Nacjonalizm humanistyczny. Jego „bohaterami” są Giovanni Papini i Giuseppe Prezzolini. Lektura tego fragmentu rozprawy habilitacyjnej rozwiewa jednak wątpliwości odnoszące się do jego tytułu. $Z$ obowiązku recenzenta odnotuję również problematykę następnych rozdziałów, wskazującą na konsekwencję autorki w stosowaniu przyjętego chronologicznego kryterium dyskursu. Kolejno mowa jest zatem o I Kongresie Nacjonalistycznym i powstaniu Stowarzyszenia Nacjonalistów Włoskich, stosunku nacjonalistów do wojny libijskiej, II Kongresie Nacjonalistycznym w 1912 r. (m.in. kwestia rozłamu między konserwatywnymi i demokratycznymi nacjonalistami) i poglądach Luigiego Federzoniego (rzecznika przymierza nacjonalistów z katolikami). Osobno zostały zaprezentowane koncepcje Alfreda Rocca, który

${ }^{33}$ Kształtowanie się w Niemczech w XIX w. idei nacjonalistycznych, z reguły w połączeniu z koncepcjami konserwatywnymi, interesująco przedstawił ostatnio w polskiej literaturze M. Kopczyński w obszernej książce Między konserwatyzmem i nacjonalizmem. Myśl polityczna Ottona von Bismarcka (Torun 2013). 
jako nieliczny spośród nacjonalistów związał się z faszystami, robiąc nawet karierę w państwie Mussoliniego ${ }^{34}$. Tematyka kolejnych rozdziałów to kwestia relacji między irredentyzmem i nacjonalizmem włoskim, nacjonalizm w przededniu I wojny światowej, stosunek włoskich nacjonalistów do tzw. sprawy polskiej na początku XX w., nacjonalistyczna krytyka liberalnego państwa włoskiego, wreszcie połączenie Stowarzyszenia Nacjonalistów Włoskich z partią faszystowską w 1923 r. W podsumowaniu swych wywodów Sondel-Cedarmas podaje przekonującą charakterystykę ideologii włoskiego nacjonalizmu, wskazując na zasadnicze odmienności między „łagodnym” nacjonalizmem XIX w. a agresywnym, wręcz imperialistycznym oraz antydemokratycznym nacjonalizmem następnego stulecia. Autorka wymienia kilkanaście cech włoskiego nacjonalizmu na przełomie XIX i XX w., m.in. ideę silnego państwa i gospodarki, kult wojny i podbojów terytorialnych, antydemokratyzm, antysocjalizm, antyliberalizm, antymasonizm, monarchizm i przymierze z Kościołem katolickim.

Osobno należy odnieść się do jednego z najważniejszych wątków przedstawionych przez Sondel-Cedarmas, a mianowicie do kwestii relacji między nacjonalizmem i faszyzmem. Przypomina mi ona nieco podobny problem badawczy, jakim było dla mnie niełatwe ustalenie związków między rewolucyjnym konserwatyzmem i nazizmem w Niemczech weimarskich i hitlerowskich $^{35}$. Oba te nurty polityczne kształtowały się przy tym niemal równolegle, podczas gdy nacjonalizm w Italii wyraźnie wyprzedzał powstanie i rozwój tamtejszego faszyzmu. Jak w przypadku Rzeszy, tak i Włoch ideowe inspiracje nie pochodziły jednak ani od nazistów, ani też od faszystów. To rewolucyjny konserwatyzm jako prąd intelektualny stał się w pewnej mierze doktrynalnym impulsem dla tych pierwszych, a mający również teoretyczną obudowę nacjonalizm - dla tych drugich. Co do tej zależności nie ma zresztą żadnych wątpliwości badaczka z Uniwersytetu Jagiellońskiego. W pełni zgadzam się z jej opinią, że wprawdzie faszyści czerpali pomysły polityczne i społeczne z różnych źródeł ideowych (m.in. od Machiavellego i Hegla), to zapewne znaczny, a nawet szczególny wpływ na doktrynę faszystowską wywarł właśnie włoski nacjonalizm. I to niezależnie od tego, jak nacjonaliści odnosili się do faszystów: pozytywnie czy negatywnie. Za autorką należy powtórzyć, że niejednego nacjonalistę włoskiego raził rewolucjonizm i republikanizm faszystów. Niejeden z nich doceniał jednak antyliberalizm i antykomunizm faszystów. $\mathrm{Ci}$ z kolei, nie będąc przecież w swej masie intelektualistami, usilnie „,rozgląda-

${ }^{34}$ A. Rocco był w latach 1924-1925 przewodniczącym Włoskiej Izby Deputowanych, a w latach 1925-1932 ministrem sprawiedliwości. Informacje na ten temat można znaleźć - gdy chodzi o nowszą literaturę dostępną w Polsce - m.in. w książce P. Foro, Włochy faszystowskie, thum. K. Jokeš, Kraków 2008.

35 Problem ten przedstawiłem m.in. w powołanej już monografii Niemieckie elity a hitleryzm... 
li się" za ideowym wsparciem dla swej politycznej działalności. To głównie z tego powodu nastąpiła w 1923 r. fuzja Stowarzyszenia Nacjonalistów Włoskich z partią pod wodzą Mussoliniego. Można zatem przyjąć, że nacjonalizm został wchłonięty przez faszyzm - podobnie jak w nazizmie „rozpłynął się” ostatecznie rewolucyjny konserwatyzm. Sondel-Cedarmas słusznie dostrzega wpływ nacjonalizmu na faszyzm w takich kwestiach, jak głoszona przez Mussoliniego et consortes koncepcja silnego państwa narodowego, solidaryzmu społecznego i korporacjonizmu oraz imperializmu i militaryzmu. Za sprawą nacjonalistów doszło również do przymierza - głównie o charakterze taktycznym - faszystów z monarchią we Włoszech. Choć nacjonaliści opowiadali się za stworzeniem silnego państwa narodowego, to jednak nie byli zwolennikami pełnej koncentracji władzy dyktatorskiej w rękach Duce, a także prowadzenia przez państwo faszystowskie polityki rasistowskiej oraz uzależnienia Włoch od III Rzeszy. Do takich pouczających i trafnych wniosków skłania lektura książki Sondel-Cedarmas. W zakończeniu tej niewątpliwie naukowo cennej monografii przydałoby się jednak dopowiedzieć, co z doktryny nacjonalistycznej przetrwało w Italii czasy faszystowskie, zwłaszcza że nacjonalizm - o czym wzmiankowałem - wciąż okazuje się ideologią inspirującą rozmaite siły polityczne we Włoszech i innych krajach europejskich. 